\title{
Towards sustainable energy system options for improving energy access in Southern Africa
}

\author{
Henerica Tazvinga ${ }^{1^{*}}$, Oliver Dzobo², Maxwell Mapako ${ }^{3}$ \\ 1 South African Weather Service, 01 Eco park Drive, Eco glades Block B, Cnr. Olievenhoutbosch and Ribbon \\ Grass Street, Centurion, Pretoria, South Africa \\ ORCiD: https://orcid.org/0000-0002-7538-6169 \\ 2 Department of Electrical and Electronic Engineering Science, University of Johannesburg, Cnr. Kingsway Road \\ \& University Road, Auckland Park, 2006, Johannesburg, South Africa \\ ORCiD: https://orcid.org/0000-0001-9602-6835
}

3 Council for Scientific and Industrial Research, P.O. Box 395, Pretoria 0001, South Africa ORCiD: $h$ ttps://orcid.org/0000-0003-4095-0329

\begin{abstract}
Access to modern energy services is one of the pre-requisites to improved livelihood, yet the poor, particularly in developing countries, remain tied to unhealthy and inefficient traditional fuels. Renewable energy technologies are increasingly popular energy supply alternatives to fossil-based fuels in many countries. This study presents sustainable energy system implementation options for increasing energy access in developing countries, with special emphasis on Sub-Saharan Africa. A feasibility case study and various implementation options are presented for possible deployment of these systems. Hybrid optimization of multiple energy resources software was used to simulate and validate the proposed hybrid system design and performance. The simulation results indicate that hybrid systems would be feasible options for distributed generation of electric power for remote locations and areas not connected to the electricity grid. Such a hybrid energy system, through providing modern energy services, gives promise to free-up rural communities to engage in productive activities. The opportunity to power or facilitate productive activities such as agro-processing, fabrication and services can potentially reduce poverty.
\end{abstract}

Keywords: hybrid system design, distributed generation, fossil-based fuels, agro-processing

\section{Highlights}

- Renewable energy technologies are becoming popular energy options.

- Provision of sustainable energy services is crucial.

- Renewable energy technologies have potential of creating income through job diversification.

- Mini grids have considerable potential in the Southern African Development Community region.

Journal of Energy in Southern Africa 31(2): 59-72

DOI: http://dx.doi.org/10.17159/2413-3051/2020/v31i2a6504

This work is licensed under a Creative Commons Attribution-ShareAlike 4.0 International Licence Published by the Energy Research Centre, University of Cape Town ISSN: 2413-3051 https://journals. assaf.org.za/jesa

Sponsored by the Department of Science and Technology

* Corresponding author: Tel: +27 (0)12 367 6276;

email: henerica.tazvinga@weathersa.co.za 


\section{Introduction}

Access to modern energy services is very important for the well-being of people and for national economic development, yet this remains limited. About 1.7 billion of the world population of just over 6 billion did not have access to electricity (International Energy Agency (IEA), 2017) in 2000. The number of people without access to electricity decreased to 1.3 billion people in 2009 and about 2.7 billion people did not have clean cooking facilities (IEA, 2011). By 2016, there was a further decrease in the number of people without access to electricity to 1.1 billion (IEA, 2017). There has, then been considerable progress worldwide in relation to electricity access, with the number of people without electricity access for the first time falling below a billion in 2017 (World Energy Outlook, 2018; IEA, International Renewable Energy Agency (IRENA), United Nations Statistics Division (UNSD), World Bank Group (WB), World Health Organisation (WHO), 2019). The same report reveals that the provision of universal electricity for all will most likely be achieved through decentralised systems, led by solar photovoltaic (PV) in off-grid and mini-grid systems, and that grid extension will still have a role to play, especially in urban areas. Most of the world's population is in developing countries, mostly in rural and remote areas where the communities are poor and marginalised.

Sub-Saharan Africa (SSA) is one region where energy poverty needs urgent attention, with 600 million people not having access to electricity and about 900 million people lacking access to clean cooking energy (IEA, 2019). Access to modern energy services is increasing at a low rate because of various factors. Achieving clean cooking for all relies primarily on the deployment of liquefied petroleum gas (LPG), natural gas and electricity in urban areas, and a range of technologies in rural areas. The IEA (2017) estimated that about 730 million people (92\% of the population) in SSA rely on traditional biomass cooking fuels such as wood, charcoal, dung and agricultural residues. About $6 \%$ of the population cooks with kerosene, which is used by $12 \%$ of urban households. The same report notes that only $32 \%$ of the urban population have access to cleaner fuels for cooking. According to IEA (2019), about 95\% of those who lack access to clean cooking use solid biomass, i.e., fuelwood, charcoal or dung in open fires), while 5\% use kerosene or coal. Reliance on these traditional fuels is detrimental to people's health, the environment and economic development. Household air pollution contributed to about 500000 million premature deaths in 2018 in SSA (IEA, 2019), because of the reliance on inefficient and polluting cook stoves. Various studies have identified several factors that influence diffusion of clean cooking that need to be considered when rolling out these technologies (Rosenthal et al., 2017; Kumar and Igdalsky, 2019; Hou et al., 2018; Abdalla and Makame, 2017). These include traditional cooking practices, cultural habits, low empowerment levels of women, and low awareness of the social, economic, health and environmental benefits of using clean technology options.

There is a growing call to address these issues and specifically to address energy poverty. Electricity demand in SSA is increasing steadily, and the future of rural electrification lies more in local, flexible and innovative decentralised production than in centralised production because of financial limitations to grid extension and the sparsely distributed household settlements. The SSA region's low rates of electrification provide a strong motivation for implementation of distributed generation systems with a high share of renewable energy (RE) technologies. Clean energy technologies are increasingly being deployed, owing to the need to reduce reliance on finite fossil-based fuels, given their impact on the environment and their increasing price. Increased uptake of $\mathrm{RE}$ sources has great potential to address the impacts of climate change on health (reducing pollutants that cause disease) and the environment, while addressing energy access and security. The main driver for implementing these technologies in SSA is to reduce energy poverty as well as address the Sustainable Developmental Goals set by the United Nations General Assembly in 2015.

According to IEA (2019), Vigolo et al., (2018) and Hou et al., (2018), the provision of sustainable energy services, especially in poor communities, is crucial in the transition from subsistence livelihoods to increased productivity, income generation and improved living standards. To support this transition, there is need for reliable power supply systems that provide uninterrupted power. These systems include a mix of dispatchable energy sources, such as diesel generators, biogas generators, fuel cells, storage batteries and the grid. Diesel generators have low initial costs, but their operation costs are high (Middlemiss and Gillard, 2015; Ogunjuyigbe et al., 2016; Tazvinga and Hove, 2010). Battery banks (typically lead-acid batteries) in PV-battery systems improve the supply reliability but sometimes they must be oversized to achieve the required hours or days of autonomy, leading to high capital costs. Oversizing of battery storage systems is often necessitated by 
the need to store more energy from the PV array when the sun is available to ensure that the user can have energy supply during periods when there is little or no production (Jadhav, et al., 2017; Taha, 1995; Quoilin et al., 2016). Battery banks are sometimes oversized to compensate for peak load supply, besides catering for increased days of autonomy (Chotia and Chowdhury, 2015). Batteries are replaced more frequently than any other component of a PV system, therefore oversizing will increase the cost of the system, hence the need for optimal sizing and design. The current decrease in PV technology prices has resulted in greater uptake of PV technology in the residential and utility sectors. Battery bank costs are also expected to reduce over time. Diesel generators, on the other hand, have been favoured options for offgrid applications for many years owing to their low initial capital costs, despite their disadvantages cited earlier.

Fuel cell (FC)-electrolyser combinations may be considered for backup and a long-term storage system, with a battery bank for short-time backup to supply transient power (Wang et al., 2008; Sichilalu et al., 2016; Wang et al., 2020). However, for the system to be environmentally friendly, the RE sources must be sized to meet the electrolyser's energy requirements for hydrogen production. Compared with internal combustion engines, FCs operate in a silent and clean mode and require less fuel, as they are more efficient. Stationary FC technology is near commercialisation and is expected to tap into a large market in residential, commercial and industrial applications in future. Currently the FC-electrolyser system is more expensive than the diesel generator system. Another challenge associated with this technology is that the production of hydrogen (electrolysis) using renewable electricity and the conversion back into electricity (FCs) is associated with energy losses and additional costs (Adefarati et al., 2017).

Biogas technology is very flexible as it utilises various types of feedstock, including the organic fraction of municipal solid wastes, waste streams from food industries, households, agriculture and agro-processing, wastewater sludge and many other organic wastes. Biogas can be produced by co-digesting various feedstocks, which are in abundance in many communities. Besides this flexibility, it contributes towards improving the energy balance, preserving natural resources, and environmental protection (Suzuki et al., 2011; Garcia, 2018). On a small scale, biogas systems are easy to build, with low capital investment costs. Many farms, institutions, businesses, households and communities can meet their energy consumption require- ments with a high level of system reliability through PV systems, and biogas plants that use animal wastes as well as other agricultural wastes as feedstock for bio-digesters to produce biogas, i.e., methane, which can then be used in combustion engines (generators) to produce electricity, while individual households can use biogas generated from co-digestion of various household and animal wastes directly from digesters to meet their thermal needs (Tazvinga et al., 2017).

Numerous hybrid energy system models have been proposed, as have a wide range of tools and methodologies for estimating costs and revenues, sizing, social and environmental impacts of various energy technologies (Fulzele and Daigavane, 2016; Tazvinga, 2015; Petrillo et al., 2016; Zakeri and Syri, 2015). While there is a global call for a shift to environment-friendly sustainable energy systems, the challenge is that systems incorporating RE sources are complex. This necessitates consideration of three dimensions of sustainability: (1) life cycle assessment; (2) social life cycle assessment; and (3) economic life cycle cost. These respectively consider environmental aspects and potential impacts associated with a service, product or process; the impacts of a product or system on the society at large; and all costs linked to the life cycle of a product or system, including externalities (Petrillo et al., 2016). The present study addresses the sustainability dimensions through analysing the benefits of using RE-based energy systems. For proper determination of the feasibility of the project/system and alternative investment choices, a life cycle cost (LCC) over the project life must be established (Leckner and Zmeureanu, 2011). In most cases, building owners and investors in RE and energy-efficient projects are interested only in the associated investment in order to make investment decisions (Rahman et al., 2015). Ogunjuyigbe et al. (2016) used a genetic algorithm to study five scenarios of RE-based hybrid systems to serve a typical load profile of a residential house with the objective of minimising the LCC, carbon emissions and dumped energy.

In this study, a systems dynamics approach is used to enhance understanding of the benefits of hybrid energy systems. The paper also presents a feasibility study of a hybrid energy system solution for meeting the rural energy needs in a sustainable way. The case study area is in Masvingo rural community, a small farming community about $40 \mathrm{~km}$ south of Masvingo, in Masvingo Province, Zimbabwe. Various generic implementation models that could be implemented are presented. The aim was to show the benefits of using RE-based systems, and that 
such a model can help address energy poverty and improve the livelihoods of the rural population. There is, however, no single solution to satisfy all community energy requirements, as each location has its own site-specific energy needs, profile and characteristics. This means that appropriate technology choices should be guided by resource availability, the energy needs of the community, and distance from current and future planned transmission grid in each location. It was also important to consider the cost of the current and proposed energy services for the proposed users to make informed choices. Hybrid optimization of multiple energy resources (HOMER) software was used for the simulation and optimisation of the system (Kumar and Deokar, 2018; Ebrahimi et al., 2019).

\section{Electrification levels for Southern African Development Community}

The Southern African Development Community (SADC), in a geographical region of SSA defined by the SADC Treaty of 1992 (SADC, 2020a), support cooperation between its member states in relation to socio-economic development, politics, defence, security and regional integration. SADC has some 26 protocols (legal agreements ratified by member states) covering many areas of collaboration including energy, trade, mining, science and technology, corruption, and shared water courses (SADC 2020b). Numerous instruments under these protocols are discussed in this section. In 1996, SADC passed the protocol on energy, which provides a framework for cooperation on energy policy among member states. Since then, the organisation and its member states have engaged in several strategies and plans to improve access to energy (Promethium Carbon, 2016). These include the Energy Activity Plan in 2000, the Energy Cooperation Policy and Strategy in 1996, the Energy Action Plan in 1997, and the Regional Infrastructure Development Master Plan and its Energy Sector Plan in 2012. In 2015, SADC endorsed the Revised Regional Indicative Strategic Development Plan (Revised RISDP) 2015-2020 to guide the implementation of SADC programmes during this period, as well as to provide approved economic and social policies and priorities. Investment in energy is covered under Priority B on Infrastructure in Support of Regional Integration, and members in the energy sector have tried to align all their activities, programmes and projects to the Revised RISDP. One of the energy targets was for at least 70\% of rural communities within southern Africa to have access to modern energy sources. This implies improved access to affordable energy services to rural communities through rural electrification and development of new and $\mathrm{RE}$ sources such as solar, biomass and wind. The 2015 SADC Industrialisation Strategy and Roadmap is another recent policy document relevant to the energy sector; among other aspects, it encourages the region to leverage its ample natural resources endowment, including energy resources, particularly $\mathrm{RE}$ ones. The strategy encourages use of clean, reliable, efficient, sustainable and cost-effective energy supply sources, while minimising greenhouse gas emissions, to address energy security. SADC's policy instruments and legal framework are in line with other regional and international commitments, such as the African Union's Agenda 2063 of 2013 which also identifies energy as one of the priority areas (SADC, 2016).

The electrification levels for SADC countries as of 2019 are shown in Table 1. It shows that, except for Mauritius, Seychelles and to a certain extent South Africa, the member states have very low electrification levels, with urban levels higher than rural. As mentioned above, many factors contribute to the low levels and to the disparities between rural and urban shares, and across countries. Many rural areas of SSA countries including the SADC region suffer from poor distribution of grid electricity and/or lack of financial resources for grid extension. There is also relatively low energy demand in most rural areas, making it uneconomic to connect them to the grid, given the high cost of longrange transmission lines. This justifies the use of more decentralised power supply systems, which are modular and can be built anywhere near the locations of use. Distributed generation options for providing power include stand-alone renewables, diesel generator sets, or a combination of these in a hybrid system. The solution for energy access in SSA and SADC lies in decentralised distributed systems based on $\mathrm{RE}$ sources. Renewable energy technologies have many well documented advantages, including environmental friendliness, and modularity, especially in the case of technologies such as solar and wind (Hove and Tazvinga, 2010; Ashok, 2007). Solar and wind technologies are, however, variable in nature and not many of the SSA countries have abundant wind resources, limiting its application in countries like Zimbabwe and Zambia. In addition, wind data for energy generation is generally not available.

\section{Benefits of renewable energy-based systems}

Provision of renewable and affordable energy is crucial for the reduction of extreme poverty and for the attainment of the United Nations 
Table 1: Electrification levels for Southern African Development Community countries.

(Index Mundi, 2019; IEA, IRENA, UNSD, WB, WHO, 2019)

\begin{tabular}{|c|c|c|c|c|}
\hline$\overline{\text { Country }}$ & Total (\%) & $\begin{array}{c}\text { Rural } \\
\text { (\% of total) }\end{array}$ & $\begin{array}{c}\text { Urban } \\
\text { (\% of total) }\end{array}$ & Access target \\
\hline Angola & 42 & 8 & 73 & $60 \%$ by 2025 \\
\hline Botswana & 63 & 38 & 80 & $100 \%$ by 2030 \\
\hline Congo (DR) & 19 & 1 & 49 & $100 \%$ by 2020 \\
\hline Lesotho & 34 & 20 & 70 & $\begin{array}{l}\text { Universal access to modern energy } \\
\text { services by } 2030\end{array}$ \\
\hline Malawi & 13 & 4 & 58 & $30 \%$ by 2030 \\
\hline Mauritius & 100 & 100 & 100 & Achieved \\
\hline Mozambique & 27 & 5 & 73 & $100 \%$ by 2030 \\
\hline Namibia & 53 & 29 & 77 & $\begin{array}{l}\text { Basic social services and infrastructural } \\
\text { facilities in urban and rural areas by } 2030\end{array}$ \\
\hline Seychelles & 100 & 100 & 100 & Achieved \\
\hline South Africa & 84 & 93 & 68 & $\begin{array}{l}100 \% \text { by } 2030 \text { with } 90 \% \text { on-grid } \\
\text { connections and remaining access } \\
\text { provided by off-grid connections. }\end{array}$ \\
\hline Swaziland & 74 & 67 & 93 & $100 \%$ by 2025 \\
\hline Tanzania & 33 & 17 & 65 & $100 \%$ by 2030 \\
\hline Zambia & 40 & 14 & 75 & $100 \%$ by 2030 \\
\hline Zimbabwe & 40 & 19 & 86 & $85 \%$ by 2020 \\
\hline Madagascar & 13 & 8 & 22 & $100 \%$ by 2030 \\
\hline
\end{tabular}

Sustainable Development Goal 7, which calls for access to affordable, reliable, sustainable and modern energy for all. Figure 1 shows an example of environmental, economic and social ben-

efits of RE-based systems. The benefits can be explained using a causal relation diagram between any two events. This exists in cases where the occurrence of one causes the other.

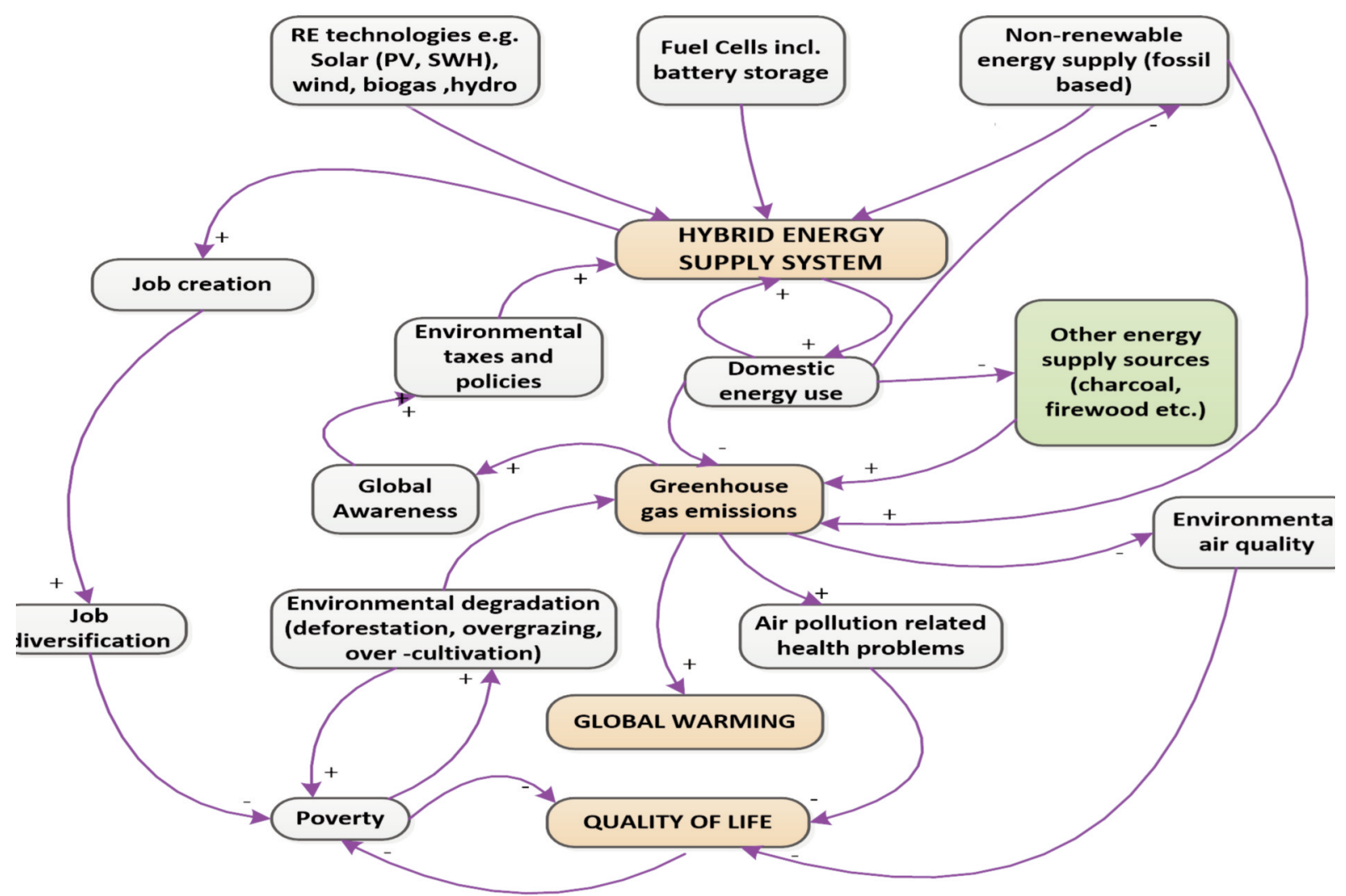

Figure 1: Environmental, economic and social benefits of renewable energy systems.

(Tazvinga and Dzobo, 2018) 
The first event is the cause and the second is the effect. A positive causal link means the two events change in the same direction. This means that if the start link decreases, the end link also decreases, and vice versa (Tazvinga et al., 2011). A reduction in greenhouse gas emissions leads to a reduction in air pollution-related health problems caused by the pollutants from fossil-based fuels. This reduction has a positive effect on the general well-being of individuals and communities.

Figure 1 shows that a decrease in fossilbased fuel usage leads to a decrease in greenhouse gases, especially carbon dioxide build-up in the atmosphere, which in turn reduces the effect of global warming. Implementation of RE-based technologies has the potential to create income through job diversification. This can lead to small enterprise development, which will in turn reduce poverty and promote sustainable rural livelihoods. Reduction in poverty results in a decrease in the traditional use of biomass (wood) and related effects such as deforestation, overgrazing and over-cultivation, as there is a correlation between poverty and environmental degradation. This is in agreement with observations by Bimenyimana and $\mathrm{Li}$ (2018). An increase in greenhouse gases increases global warming and, to mitigate this effect, there is a need to intensify awareness that can be achieved through educating people on the use of clean RE technologies to reduce the carbon footprint. The increase in greenhouse gas emissions results in increased need for awareness campaigns and implementation of various policies supporting uptake of RE-based energy systems and introduction of environmental taxes, resulting in increased use of RE-based hybrid systems. Increased usage of RE systems then results in a decrease in greenhouse gas emissions and global warming.

\subsection{Industry implementation models}

SADC has put in place various policies and strategies to address energy access through increased uptake of clean and RE technologies. In light of this, the present study presents some innovative $\mathrm{RE}$ implementation models that can be used to encourage widespread affordability and acceptance of RE technologies in the SADC region, based on global experiences (IEA Photovoltaic Power Systems (PVPS) Task 9, 2003). When developing a new RE market, it is important to make informed choices of the most appropriate implementation models. It is critical to note that the local conditions require tailored solutions and approaches, or combinations of the models described here. The three generic models are:
- Model 1 - Cash sales: The RE supplier sells the RE system directly or through a dealer to the end-user who becomes the owner of the system.

- Model 2 - Credit sales: The end-user acquires the RE system on credit. The credit sales are divided into three categories:

- Dealer credit: The RE supplier/dealer sells the system to the end-user, who also enters into a credit arrangement with the supplier/dealer. Depending on the arrangements, the end-user takes delivery of the system, immediately or when all payments are made.

- End-user credit: The supplier/dealer sells the system to the end-user, who obtains consumer credit from a third-party credit institution. The end-user usually takes delivery of the system immediately, or when all payments are made.

- Lease/hire-purchase: The supplier/dealer or a financial intermediary leases the system to the end-user: At the end of the lease period, ownership may or may not be transferred to the end-user, depending on the arrangements. During the lease period, the lessor remains owner of the system and is responsible for its maintenance and repair.

- Model 3 - Fee for service: An electricity supply company (ESCO) owns the system and provides energy services to the end-user, who pays a periodic fee, e.g., monthly, to the ESCO. The end-user is not responsible for the maintenance of the $\mathrm{RE}$ system and never becomes the owner, although the end-user may own, e.g., the battery and lamps/radio/gas stove.

Another concept linked to hybrid systems is the micro/mini-grids concept. Mini-grids can be made of single or multiple generation sources. Mini-grids have considerable potential in the SADC region, but their success lies in the implementation model adopted. The business models for mini-grids may include, but are not limited to, the following categories (Roland and Glania, 2011):

- Community-based model: The community owns and operates the mini-grid, with a cooperative often established to own and manage the system. This model usually relies on initial capital support from governments or philanthropic organisations, as well as technical support for project implementation. This model is good in that it is owned by the community and can create employment opportunities for locals, and engagement with all parties involved is easy 
at all levels. However, there is need for a lot of support as communities often lack technical skills and business experience and for measures to be in place to manage any conflicts that can adversely affect project success.

- Private sector-based model: A private organisation (or organisations) manages the construction and operation of the mini-grid, with varying levels of external financial support, depending on the level of government involvement and type of subsidies available. In this model, skills and experience are the key potential success factors. Financial viability is important, therefore once the business case is established the chances of failure are reduced. The problems associated include the possibility of focusing more on profit than serving the community and use of inexperienced personnel.

- Utility-based model: The national utility is responsible for the construction and operation of the mini-grid. This model has high chance of success because utilities can easily access public-sector financing mechanisms and have experience with electrification projects. However, this model is prone to bureaucratic red tape and delays, external political interference and some utilities may have bias towards grid electrification as opposed to micro-grids from a cost or other perspective.

- Hybrid model: This involves various combinations, such as public-private partnerships where the government finances the construction of a mini-grid that is then managed by a private organisation, or a privately-owned mini grid that is maintained by the community that it serves. As the name implies, this model has high chances of success by combining the benefits of other models.

Related to the mini-grid models are the associated tariffs that could be implemented, and these tariffs directly affect sustainability of the mini-grid as well as willingness of developers to venture into this business. Considering that the payback period for mini-grids can be long, the political and regulatory environment are important factors for long-term business model sustainability. Developers and investors want to be confident that any agreements, tariff approvals or subsidies on which their financial and operational viability depends will be valid for the duration - ideally at least ten years - to ensure not only cost-recovery but also profitability. Otherwise key dependencies of their business model may suddenly become annulled. Simi- larly, developers desire confidence to sell to the grid at an agreed tariff or be otherwise compensated for their assets if the national grid does eventually expand into their service territory.

\section{Feasibility case study}

The present study considered a feasibility case study of a Zimbabwean rural farming community. As in most SSA and developing countries, energy access remains a big challenge in Zimbabwe, with a rural electrification level of below 40\% as reflected in IEA (2019). There have been many initiatives to address the energy access issue by the government and donor agencies, but there is still a big gap (Bhattacharyya et al., 2012). The country's energy supply is mostly from hydroelectric power and from a few thermal coal power plants. It has experienced power shortages in recent years and some urban households have responded by installing PV and solar waterheating systems as well as diesel and petrol generators in urban and off-grid locations. Innovative solar technology applications such as in street lighting and traffic controls have been demonstrated in some urban areas. It was found that $80-90 \%$ of the rural population relies on wood fuel and kerosene for cooking and lighting (energypedia, 2019). A high proportion of the rural population consists of peasant farmers, who mostly grow maize. Grain-milling is thus an important processing activity in most of these communities and it is usually carried out by diesel-powered mills. Renewable energy technologies can play an important role in activities such as water-pumping, grain-milling, cellphone-charging, hair salons, battery-charging, and lighting. Improved lighting extends study times for learners in rural communities. Small businesses within the communities may go a long way in improving livelihoods (Magrath, 2015). Although energy access does not necessarily guarantee gender equality, which is also a big challenge globally, it is an important step towards the emancipation of women by enabling them to have more time to engage in productive activities (Bazilian et al., 2012). An example of solar technology application in rural communities in Zimbabwe is the solar-powered borehole water supply for Masasa Clinic, primary and secondary schools, donated by the Chandiwana Memorial Foundation with support from Frinton Free Church, United Kingdom and Masasa Community in Chivhu, a small farming community about $140 \mathrm{~km}$ south of Harare, in Mashonaland East Province, Zimbabwe. The community now have access to clean water and do not have to travel long distances to fetch water. Like other 
SSA countries, Zimbabwe has a limited supply of electricity because of poor distribution of grid electricity and lack of financial resources for grid extension and generation expansion. In addition, the relatively low energy demand in most rural areas justifies use of decentralised power supply systems.

\subsection{System configuration}

The considered system architecture is as shown in Figure 2. The system is made up of a PV generator, diesel generator, and battery storage. The PV generator supplies the load whenever PV output is available, otherwise the battery storage is dispatched, provided it is within its operating limits to meet the supply shortfall. If both PV and battery cannot meet the load, the diesel generator is dispatched to ensure that the load is fully satisfied and to charge the battery. The PV generator also charges the battery when there is excess PV generation. The system design minimises of usage the diesel generator while maximising utilisation of solar energy when available thus limiting diesel generator operation and related maintenance costs.

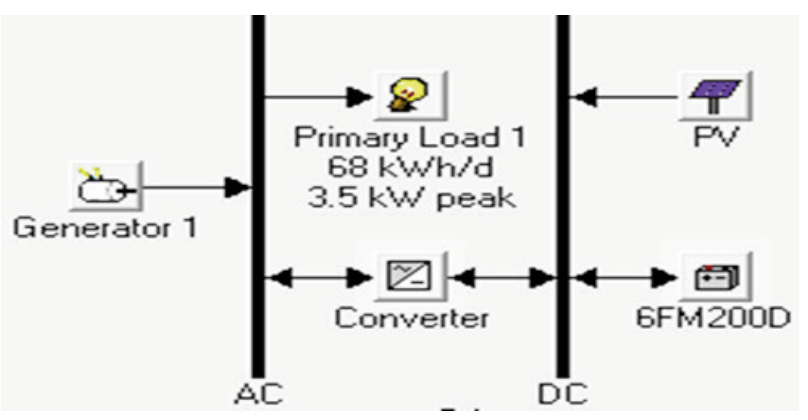

Figure 2: System configuration, where PV, DC and $A C=$ photovoltaic, direct current, and alternating current respectively.

\subsection{Optimal system considerations}

A global standard software for optimising microgrid design, HOMER, was used to optimise the system under study. An average daily load profile for the selected rural community was obtained using a methodology developed by Hove and Tazvinga (2010). This load data was used as input in the Homer software to produce monthly profiles as shown in Figure 3. An energy demand survey was carried out at the potential site, and the energy demand analysis was performed in accordance with the methodology shown in Table 2. This shows a sample of required appliances or equipment details such as their number and nominal power that was subsequently multiplied by the number of hours of operation on a typical day.

The total power was obtained by multiplying the appliance number by the power rating of
Table 2: Demand analysis data.

\begin{tabular}{lcccc}
\hline $\begin{array}{l}\text { Code } \\
\text { no. }\end{array}$ & Appliance & No. & $\begin{array}{c}\text { Power } \\
\text { rating }(W)\end{array}$ & $\begin{array}{c}\text { Total } \\
\text { power }(W)\end{array}$ \\
\hline 1 & Drug refrigerator & 1 & 300 & 300 \\
2 & Clinic lights & 15 & 20 & 300 \\
3 & Computer & 1 & 150 & 150 \\
\hline
\end{tabular}

Table 3: Appliance usage matrix.

\begin{tabular}{llllllllll}
\hline Time & \multicolumn{10}{c}{ Appliances in use } \\
(hr) & 1 & 2 & 3 & 4 & 5 & 6 & 7 & 8 & 9 \\
\hline $1: 00$ & 1 & 1 & 0 & 0 & 0 & 0 & 1 & 0 & 0 \\
$2: 00$ & 1 & 1 & 0 & 0 & 0 & 0 & 1 & 0 & 0 \\
$3: 00$ & 1 & 1 & 0 & 0 & 0 & 0 & 1 & 0 & 0 \\
$4: 00$ & 1 & 1 & 0 & 0 & 0 & 0 & 1 & 0 & 0 \\
$5: 00$ & 1 & 1 & 0 & 0 & 0 & 0 & 1 & 0 & 1 \\
\hline
\end{tabular}

Table 4: Load profile.

\begin{tabular}{cc}
\hline Time & Load $(k W)$ \\
\hline 0 & 0 \\
1 & 1.5 \\
2 & 1.5 \\
3 & 1.5 \\
4 & 1.5 \\
\hline
\end{tabular}

each appliance, resulting in an $\mathrm{N} \times 1$ matrix, where $\mathrm{N}$ is the number of appliances. Table 3 shows that an appliance usage matrix was then developed, which is a method convenient for the computation of the load data. The table shows the time of the day and the appliance in use for each hour. This $24 \times \mathrm{N}$ matrix, when multiplied by the $\mathrm{N} \times 1$ matrix, results in a $1 \times$ 24 matrix that represents the load as shown in Table 4. The load profile was then used as input in the Homer software to produce the monthly profiles shown in Figure 3.

The solar resource data used for a location at -20.079 latitude and 30.838 longitude in Masvingo Rural District in Zimbabwe was obtained online (NASA Open data portal, nd). This was used for the study area in the same province because of the unavailability of data at the actual location. The annual average solar radiation was $5.427 \mathrm{kWh} / \mathrm{m}^{2} /$ day and the average clearness index was 0.542 . Figure 4 shows the annual radiation and clearness index for a location in Masvingo. Clearness index is a dimensionless parameter that indicates the fraction of the solar radiation striking the top of the atmosphere that makes it through the atmosphere to strike the earth's surface.

For the system design, the cost of a $1.5 \mathrm{~kW}$ converter was set at USD 900 with a replacement cost of $80 \%$ of the capital cost, $90 \%$ efficiency and lifetime of 15 years. Converter sizes were optimised between 0 and $6 \mathrm{~kW}$. The diesel 

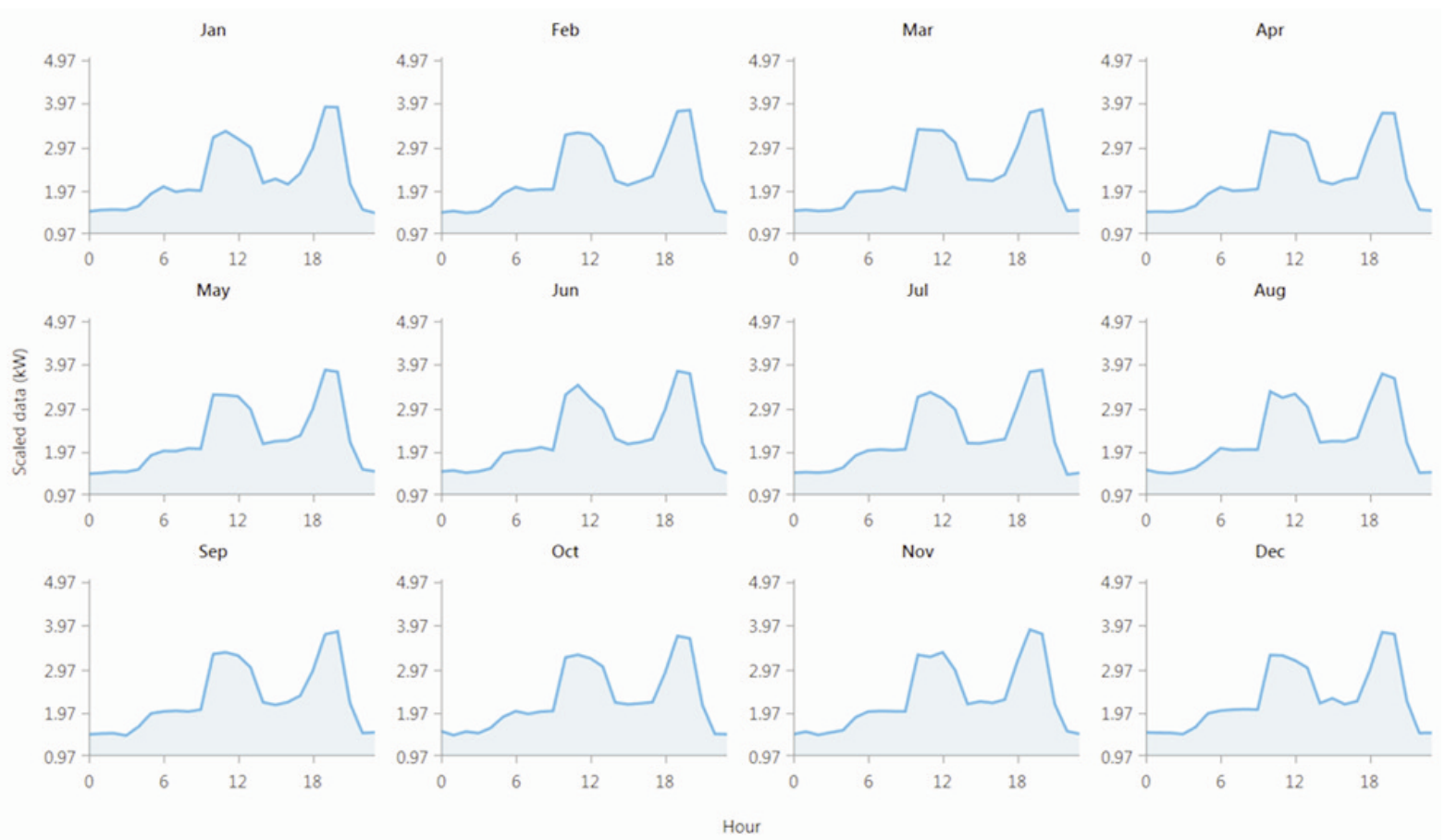

Note: The names of the months are abbreviated.

Figure 3: Scaled average daily load profile.

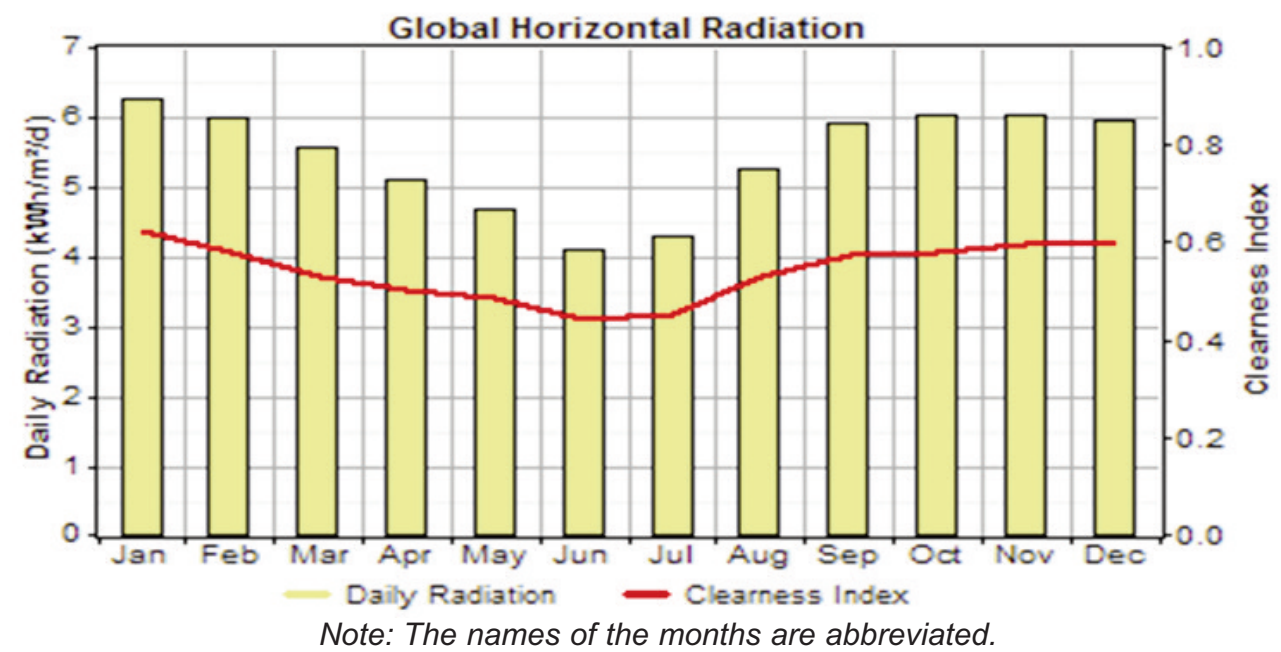

Figure 4: Average daily radiation and clearness index.

generator should not run at less than the minimum load ratio of $30 \%$. The diesel generator was optimised within the range $0-5.5 \mathrm{~kW}$ at a cost of USD 1500 , lifetime of 15000 hours, and the price of diesel in Zimbabwe was set at USD 1.20/litre. A diesel generator sometimes does not need to be equal or above the peak load.The Vision 6FM200D from Vision Battery with a nominal capacity of 200 Ah (2.4 kWh) and nominal voltage of $12 \mathrm{~V}$ for a single battery was used; and quantities optimised in the range of 0 3 batteries. The battery efficiency was set at $80 \%$ with a minimum state of charge of $40 \%$ and a cost of USD 400 per battery. For system sizing, solar PV capacity was optimised between 0 and $5 \mathrm{~kW}$ and panel sizes of $100 \mathrm{~W}, 250 \mathrm{~W}$ and $300 \mathrm{~W}$ from Enersol were considered, at a cost of USD $1.50 / \mathrm{W}$. The rated power of the inverter was determined using the peak load. It is important to choose an inverter that will satisfy a system's peak-load requirements. Most inverters can exceed their rated wattage for limited periods of time. This is necessary since appliances may require many times their rated wattage during start up and to accommodate the minimum surge requirement. The power rating to match the inverter specifications was achieved by multiplying the peak power by a factor of 1.2 to account for inverter loss. Some inverters have the added advantage that they have a built-in battery charger so that when the batteries need charging from an AC source (generator), the current can be fed into the inverter, changed to DC and then used. 


\section{Results and discussion}

The optimised results in Table 5 show the combination with the lowest cost of energy as the best option and this constitutes a $5 \mathrm{~kW} \mathrm{PV}, 2.5$ $\mathrm{kW}$ diesel generator and one $2.4 \mathrm{kWh}$ battery. The dispatch strategy is the load following one. The operation of the system as observed from the results is such that the use of PV is maximised during the day when the sun is available, while the use of the generator is minimised as much as possible, considering the operation and maintenance cost of the diesel generator. The PV system supplies energy during the daytime and charges the battery. During periods when the PV output is not enough to match the load, the battery comes in to match the shortfall, provided its charge is within its operating limits. When both PV and battery output cannot meet the load, the diesel generator comes in to meet the imbalance. The diesel generator runs mostly during the night from about $18 \mathrm{~h} 00$ and during morning hours for the feasibility study area considered in this study. The PV system operates during the day, while both the battery and generator come in to match the load whenever the PV output cannot meet the load on its own. When compared with the diesel generator only case, the annual operating cost is much higher than for the optimal system although the initial cost is low for this case. The difference in the cost of energy for the two scenarios, i.e., optimal and diesel only, is a significant $33.95 \%$. The percentage difference in diesel consumption is 50\%, showing a significant reduction in fuel consumption owing to the use of a hybrid energy system, i.e., optimal system.

Table 5 shows a sample of the optimised technologies or systems. The PV/DG/B was the most optimum option out of the optimised combinations. Although the diesel generator-only option had the least initial capital costs, it was the least optimum solution because of other associated costs.

These results show that households and institutions in developing countries such as Zimbabwe which currently use only diesel generators for their operations can save money by incorporating PV and storage in their energy supply mix. The simple and discounted payback periods are 2.64 and 2.85 years respectively. This is attractive for those willing to invest in such systems. Figure 5 shows the cash flow summary for the different system components. Fuel consumption is revealed as the major cost of concern. The diesel generator replacement costs are also significant compared to battery and converter replacement costs. The operational costs and salvage value were low. The PV investment costs were more significant than the costs of the other components, but there are no replacement costs in the lifetime of the system.

Figure 6 shows the average monthly electricity generation by the PV and diesel generator systems. The PV contribution is significant with a penetration rate of $43.4 \%$. As expected, PV generation is low in winter months and higher in summer months. PV penetration refers to the ratio of total peak PV power to peak load apparent power, while the renewable fraction is the fraction of the energy delivered to the load that originated from renewable power sources.

It is critical to consider the cost of extending the grid to determine the cost-effectiveness of an isolated system. The breakeven grid extension distance is the distance from the grid that makes the net present cost of extending the grid equal to the net present cost of the stand-alone system; in this case it was $7.15 \mathrm{~km}$. The net present cost or life-cycle cost of a system is the present value of all the costs of installing and operating that system over the project lifetime, minus the present value of all the revenues it earns over the project lifetime. The stand-alone system is optimal for a location far from the grid and grid extension is optimal nearer to the grid. This means that, in terms of cost, it is only economical to connect the grid for distances less than $7.15 \mathrm{~km}$, while it does not make any economic sense for any distance exceeding $7.15 \mathrm{~km}$. The grid is far from the site considered, making prospects of being connected unlikely, as it will be too expensive.

It is known that solar PV alone, even on a high-power production day, cannot meet the load as it is only available during the day. For

Table 5: Optimised results.

\begin{tabular}{lcccccccccccc}
\hline System & $\begin{array}{c}P V \\
(k W)\end{array}$ & $\begin{array}{c}D G \\
(k W)\end{array}$ & $\begin{array}{c}B \\
(k W h)\end{array}$ & $\begin{array}{c}\text { Co } \\
(k W)\end{array}$ & $\begin{array}{c}I C \\
(U S D)\end{array}$ & $\begin{array}{c}\text { OC } \\
(U S D / y r)\end{array}$ & $\begin{array}{c}\text { TNPC } \\
(U S D)\end{array}$ & $\begin{array}{c}C O E \\
(U S D / k W h)\end{array}$ & $\begin{array}{c}R E F \\
(\%)\end{array}$ & $\begin{array}{c}C S \\
(\%)\end{array}$ & $\begin{array}{c}D \\
(L)\end{array}$ & $\begin{array}{c}O H \\
(h r)\end{array}$ \\
\hline PV/DG/B & 5 & 2.5 & 1 & 3 & 11538 & 6764 & 98001 & 0.428 & 34 & 2 & 4967 & 7161 \\
PV/DG & 5 & 2.5 & 0 & 3 & 11138 & 6830 & 98444 & 0.434 & 32 & 3 & 5137 & 7553 \\
DG/B & 0 & 2.5 & 1 & 1 & 2238 & 9773 & 127172 & 0.553 & 0 & 1 & 7277 & 8760 \\
DG & 0 & 4 & 0 & 0 & 1500 & 10896 & 140785 & 0.603 & 0 & 0 & 8278 & 8760 \\
\hline
\end{tabular}

Note: $P V=$ photovoltaic, $D G=$ diesel generator, $B=$ battery, $C o=$ converter, $I C=$ initial capital, TNPC $=$ total net present cost, $C O E=$ cost of energy, $R E F=$ renewable energy fraction, $C S=$ capacity shortage, $D=$ diesel, $\mathrm{OH}=$ operating hours. 


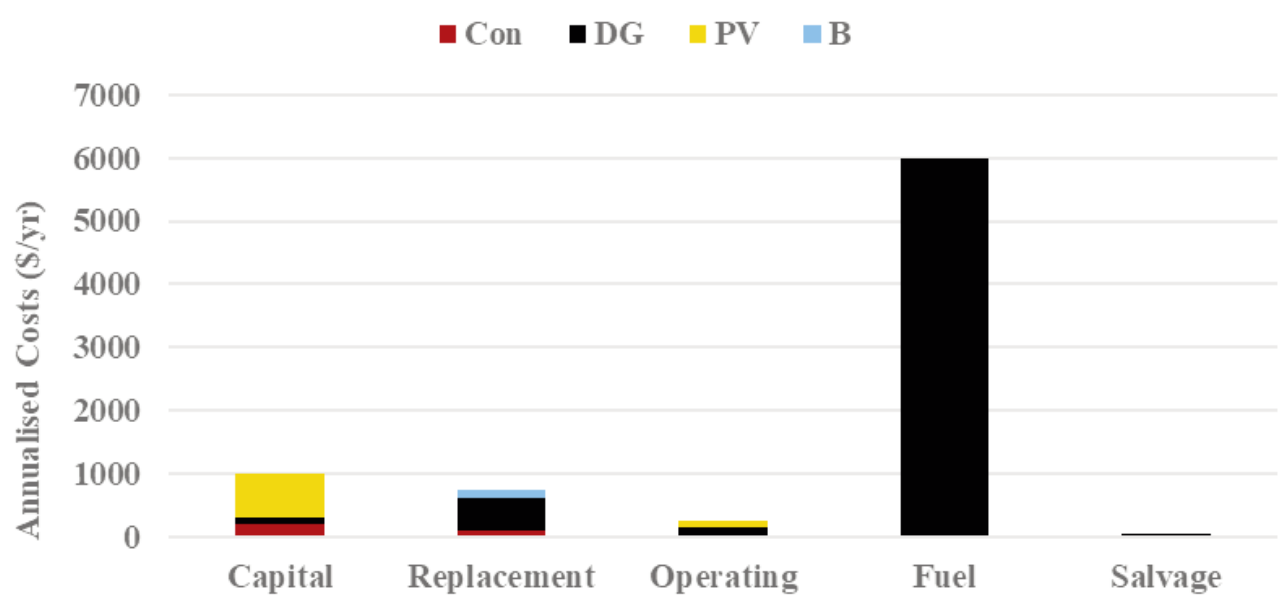

Note: Con = converter, $P V=$ photovoltaic, $D G=$ diesel generator, $B=$ battery

Figure 5: Optimal system cash flow summary.

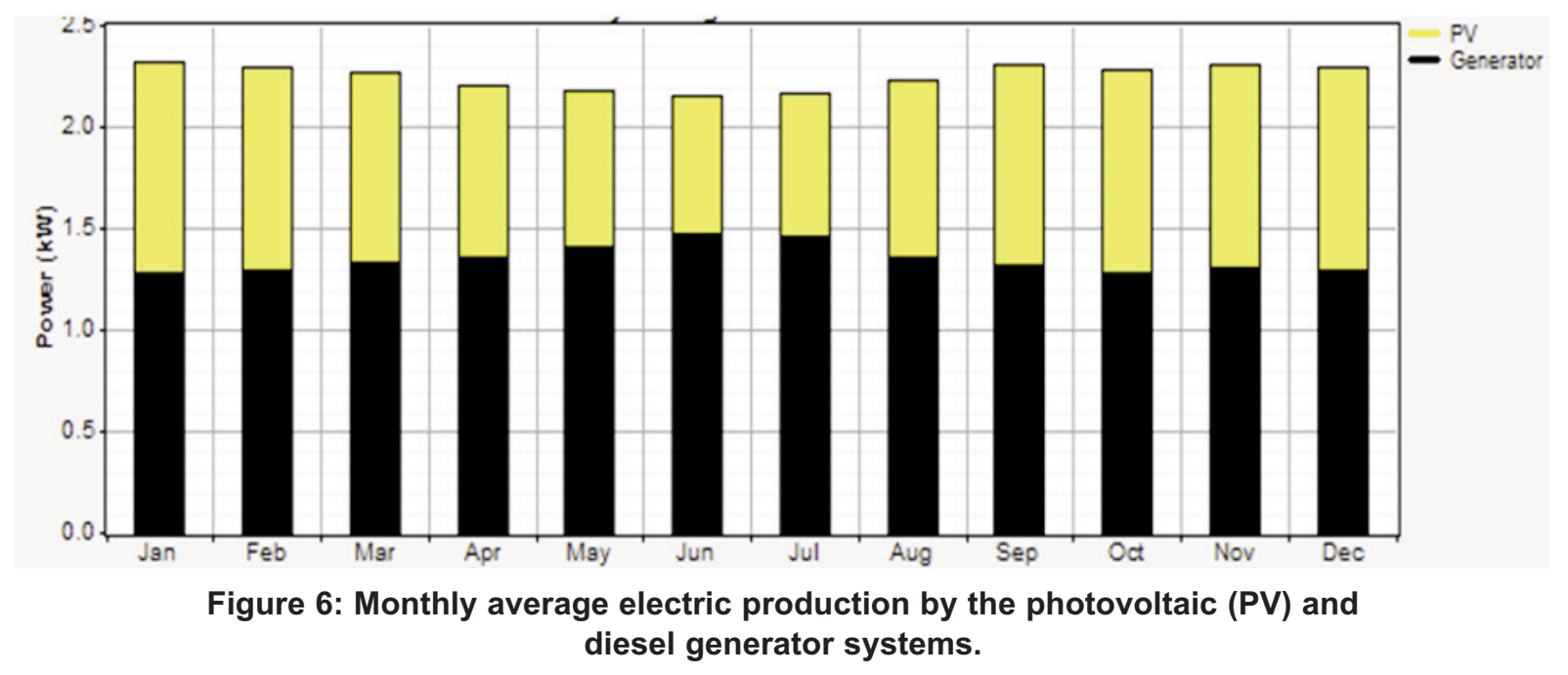

the diesel generator to meet the load there are considerable costs involved in terms of fuel and maintenance costs. Combining PV and diesel generator systems results in fuel savings and reduced air pollution. It is beneficial for the communities to use clean energy for their daily activities when sunshine is available. The results of the feasibility study have shown that, if an optimal system is implemented, the PV system would supply energy during the day and, if the energy is insufficient to meet the load, the battery would cater for the imbalance. In cases when both the PV system and the battery cannot meet the load, the generator would switch on to meet the imbalance, otherwise the generator would mostly run during night when the sun is not available and when the battery charge is lower than the minimum permissible limits. Such a hybrid energy system was shown to be a feasible solution for providing energy to rural communities and hence have the potential to enable the communities to engage in more productive activities owing to reduced time spent on activities such as walking long distances to fetch water, as water-pumping for domestic use and from boreholes would be possible. Energy provision also has the potential to enable economic activities through the availability of solar lights, cell phone- and batterycharging, as well as increased agricultural productivity through the use of the hybrid system for water-pumping. Use of fossil fuel-based options and batteries in rural communities, especially at household level, remain a big challenge due to the high operational, maintenance, and replacement costs.

While the feasibility case study was done for a community in the Masvingo rural community in Zimbabwe, such systems can easily be replicated in any country within the SADC or SSA region, given the good solar resources present. Implementation of similar systems in mini-grids, has great potential to contribute to energy access, while contributing to sustainable development goals and climate change mitigation. Diesel-only systems readily exist within the region in households and mini-grids. With supporting policies, hybrid PV, diesel and battery systems have the potential to play a role in the $\mathrm{SADC}$ or SSA region, given the drastic reduc- 
tion in the cost of PV systems in recent years and the continued decrease in costs of battery storage systems. Increasing the PV system contribution has a great potential to increase savings on diesel, while maintaining the hybrid system's supply reliability. It is also important for individuals, developers and investors or other interested parties to choose the most favourable and sustainable implementation model for both single household systems and micro/mini-grid options.

\section{Conclusions}

This study has cited research showing that poverty remains one of the seemingly intractable problems facing the world, with the majority of people in the developing regions of the world living without access to many services. One of these is modern energy services, which have the potential to improve health through a cleaner environment, and to facilitate and power productive activities. This could help to pull remote communities out of poverty. Using the Hybrid Optimization of Multiple Energy Resources software and data from a remote study site in Zimbabwe, this study showed that a hybrid power-generating system would be viable in an off-grid community in a developing country in sub-Saharan Africa. Typical productive activities in the region, including fabrication, recycling, agro-processing and other services can be powered by such hybrid systems which can potentially be adapted and replicated in different countries. The hybrid system presented in this work has potential for replication in other rural settings in southern Africa, given its good solar resources.

\section{Acknowledgements}

The authors acknowledge the support for this work provided by the Council for Scientific and Industrial Research, the National Research Foundation of South Africa and the University of Johannesburg, South Africa.

\section{Author roles}

Henerica Tazvinga: research formulation, data collection, case study system design and simulations, analytical techniques, implementation models, write-up.

Oliver Dzobo: research formulation, data collection, case study system design and simulations.

Maxwell Mapako: research formulation, implementation models, checked the results of the case study and reviewed the text.

\section{References}

Abdalla, H.S. and Makame, O.M. 2017. Adoption of the new highly efficient cooking stoves by urban households in Zanzibar, Tanzania. Journal of Development and Agricultural Economics, 9(11): 320-327.

Adefarati, T., Papy, N.B., Thopil, M. and Tazvinga, H. 2017. Non-renewable distributed generation technologies: A review. In Handbook of Distributed Generation, 69-105. Springer, Cham.

Ashok, S. 2007. Optimised model for community-based hybrid energy system. Renewable Energy, 32(7): 1155-1164.

Bazilian, M., Nussbaumer, P., Rogner, H.H., Brew-Hammond, A., Foster, V., Pachauri, S., Williams, E., Howells, M., Niyongabo, P., Musaba, L. and Gallachóir, B.Ó. 2012. Energy access scenarios to 2030 for the power sector in sub-Saharan Africa. Utilities Policy, 20(1): 1-16.

Bhattacharyya, S.C. 2012. Energy access programmes and sustainable development: A critical review and analysis. Energy for sustainable development, 16(3): 260-271.

Bimenyimana, S., Asemota, G.N. and Li, L. 2018. The state of the power sector in Rwanda: a progressive sector with ambitious targets. Frontiers in Energy Research, 6: 68.

Chotia, I. and Chowdhury, S. 2015, November. Battery storage and hybrid battery supercapacitor storage systems: A comparative critical review. IEEE Innovative Smart Grid Technologies, Asia (ISGT ASIA), 1-6.

Ebrahimi, S., Jahangiri, M., Raiesi, H.A. and Ariae, A.R. 2019. Optimal planning of on-grid hybrid microgrid for remote Island Using HOMER software. Kish in Iran. International Journal of Energy, 3(2): 1321.

Fulzele, J.B. and Daigavane, M.B. 2015. Optimization of PV-wind hybrid renewable energy system for rural electrification. In 2015 7th International Conference on Emerging Trends in Engineering \& Technology. Kobe, Japan, November 18-20, IEEE. 101-105.

Hou, B., Liao, H. and Huang, J. 2018. Household cooking fuel choice and economic poverty: evidence from a nationwide survey in China. Energy and Buildings, 166, pp.319-329.

Index Mundi, 2019, Accessed 01/06/2020), https://www.indexmundi.com/factbook/countries

IEA [International Energy Agency]. 2014. Energy in Africa Today, Africa Energy Outlook, https://www.iea.org/publications/freepublications/publication/africa-energy-outlook.html. 
IEA [International Energy Agency]. 2014. Africa Energy Outlook: World Energy Outlook Special Report, OECD/IEA, Paris.

IEA [International Energy Agency]. 2019. Africa Energy Outlook: Special Report, OECD/IEA, Paris. https://webstore.iea.org/world-energy-outlook-2019

IEA [International Energy Agency]. 2017. WEO-2017 Special Report: Energy Access Outlook, OECD/IEA, Paris.

IEA [International Energy Agency], IRENA [International Renewable Energy Agency], UNSD [United Nations Statistics Division], WB [World Bank], WHO [World Health Organization]. 2019. Tracking SDG 7: The Energy Progress Report 2019, International Bank for Reconstruction and Development, Washington DC.

IEA [International Energy Agency], PVPS [Photovoltaic Power Systems]. 2003. 16 Case Studies on the Deployment of Photovoltaic Technologies in Developing Countries. Available at: http://www.ieapvps.org.

Jadhav, A.S., Chembe, D.K., Strauss, J.M. and Van Niekerk, J.L. 2017. Status of solar technology implementation in the Southern African Developing Community (SADC) region. Renewable and Sustainable Energy Reviews, 73: 622-631.

Khatib, H. 2012. IEA world energy outlook 2011 - A comment. Energy Policy, 48: 737-743.

Kumar, P. and Deokar, S. 2018. Optimal design configuration using HOMER. Advances in Systems, Control and Automation, 101-108. Springer, Singapore.

Kumar, P. and Igdalsky, L. 2019. Sustained uptake of clean cooking practices in poor communities: role of social networks. Energy research \& social science, 48: 189-193.

Leckner, M. and Zmeureanu, R. 2011. Life cycle cost and energy analysis of a Net Zero Energy House with solar combisystem. Applied Energy, 88(1): 232-241.

Magrath, J. 2015. Transforming lives in Zimbabwe: Rural sustainable energy development project. Oxford, UK: Oxfam GB.

Middlemiss, L. and Gillard, R. 2015. Fuel poverty from the bottom-up: Characterising household energy vulnerability through the lived experience of the fuel poor. Energy Research \& Social Science, 6: 146154.

NASA [Surface Meteorology and Solar Energy] Open Data Portal (no date). Surface Meteorology and Solar Energy | Available at: https://data.nasa.gov/Earth-Science/Surface-Meteorology-and-SolarEnergy/wn3p-qsan (Accessed: 31 January 2019).

Ogunjuyigbe, A.S.O., Ayodele, T.R. and Akinola, O.A. 2016. Optimal allocation and sizing of $\mathrm{PV} /$ Wind/Split-diesel/Battery hybrid energy system for minimizing life cycle cost, carbon emission and dump energy of remote residential building. Applied Energy, 171: 153-171.

Petrillo, A., De Felice, F., Jannelli, E., Autorino, C., Minutillo, M. and Lavadera, A.L. 2016. Life cycle assessment (LCA) and life cycle cost (LCC) analysis model for a stand-alone hybrid renewable energy system. Renewable energy, 95: 337-355.

Promethium C. 2016. Electricity Market Reform in Southern Africa. Promethium Carbon, Johannesburg.

Quoilin, S., Kavvadias, K., Mercier, A., Pappone, I. and Zucker, A. 2016. Quantifying self-consumption linked to solar home battery systems: Statistical analysis and economic assessment. Applied Energy, 182: 58-67.

Rahman, H.A., Majid, M.S., Jordehi, A.R., Kim, G.C., Hassan, M.Y. and Fadhl, S.O. 2015. Operation and control strategies of integrated distributed energy resources: A review. Renewable and Sustainable Energy Reviews, 51:1412-1420.

Roland, S. and Glania, G. 2011. Hybrid mini-grids for rural electrification: Lessons learnt. Alliance for Rural Electrification (ARE)/USAID. Brussels, Belgium.

Rosenthal, J., Balakrishnan, K., Bruce, N., Chambers, D., Graham, J., Jack, D., Kline, L., Masera, O., Mehta, S., Mercado, I.R. and Neta, G. 2017. Implementation science to accelerate clean cooking for public health. Environmental health perspectives, 125(1): A3-A7.

SADC [Southern African Development Community], 2020a. History and Treaty. https://www.sadc.int/about-sadc/overview/history-and-treaty/. Accessed 22 May 2020.

SADC [Southern African Development Community], 2020b. SADC Protocols. https://www.sadc.int/about-sadc/overview/sa-protocols/. Accessed 22 May 2020.

SADC [Southern African Development Community], SARDC [Southern African Research and Documentation Centre], 2016. SADC Energy Monitor 2016: Baseline Study of the SADC Energy Sector. Southern African Development Community and Southern African Research and Documentation Centre, Gaborone and Harare.

SADC [Southern African Development Community], SARDC [Southern African Research and Documentation Centre]. 2018. SADC Energy Monitor 2018 - Enabling Industrialization and Regional 
Integration in SADC. SADC, SARDC. Gaborone, Harare.

SADC [Southern African Development Community], 2016. Renewable Energy and Energy Efficiency Strategy \& Action Plan: REEESAP 2016-2030. Southern African Development Community, Gaborone.

Sichilalu, S., Tazvinga, H. and Xia, X. 2016. Optimal control of a fuel cell/wind/PV/grid hybrid system with thermal heat pump load. Solar Energy, 135: 59-69.

Suzuki, A.B.P., Fernandes, D.M., Faria, R.A.P. and Vidal, T.C.M. 2011. Use of biogas in internal combustion engines. Applied Research \& Agrotechnology, 4(1): 221-237.

Taha, A.Z. 1995. The oversizing method of estimation in PV systems. Renewable energy, 6(5-6): 487-490.

Tazvinga, H. 2015. Energy optimisation and management of off-grid hybrid power supply systems (Doctoral dissertation), University of Pretoria, South Africa.

Tazvinga, H., Amigun, B., Stafford, W.H. and Mapako, M. 2011. Can solar-biogas hybrid systems be the solution to sustainable energy supply in rural areas? Nineteenth Conference on Domestic use of energy. Cape Town: Cape Peninsula University, 12-13 April, 2011, 203-208.

Tazvinga, H. and Dzobo, O. 2018, April. Hybrid energy systems for rural communities in Zimbabwe. In Proceedings of the EAI International Conference on Research, Innovation and Development for Africa: 480-492. Institute for Computer Sciences, Social-Informatics and Telecommunications Engineering.

Tazvinga, H. and Hove, T. 2010. Photovoltaic/diesel/battery hybrid power supply system. VDM Publishers.

Tazvinga, H. and Hove, T. 2010. Technical model for optimising PV/diesel/battery hybrid power systems, 3rd CSIR Biennial Conference, CSIR International Convention Centre: Pretoria, 1 August - 01 September 2010. Available at: http://researchspace.csir.co.za/dspace/handle/10204/4229.

Tazvinga, H., Thopil, M., Numbi, P.B. and Adefarati, T. 2017. Distributed renewable energy technologies. In Handbook of Distributed Generation (pp. 3-67). Springer, Cham.

Wang, C. and Nehrir, M.H. 2008. Power management of a stand-alone wind/photovoltaic/fuel cell energy system. IEEE transactions on energy conversion, 23(3): 957-967.

Wang, Y., Diaz, D.F.R., Chen, K.S., Wang, Z. and Adroher, X.C. 2020. Materials, technological status, and fundamentals of PEM fuel cells-a review. Materials Today, 32: 178-203.

Vigolo, V., Sallaku, R. and Testa, F. 2018. Drivers and barriers to clean cooking: A systematic literature review from a consumer behaviour perspective. Sustainability, 10(11): 4322.

Wellinger, A., Murphy, J.D. and Baxter, D. eds. 2013. The biogas handbook: science, production and applications. Elsevier.

Zakeri, B. and Syri, S. 2015. Electrical energy storage systems: A comparative life cycle cost analysis. Renewable and Sustainable Energy Reviews, 42: 569-596. 